\title{
A Survey of Contemporary African American Poetry, Drama, \& Fiction
}

\author{
Lilly Fernandes \\ Associate Professor \\ Department of English \\ Al Jouf University, Sakaka \\ Kingdom of Saudi Arabia \\ Cell No: +966538251852_＜noBreak>E-mail: dr.lillyfernandes@gmail.com
}

Received: 16-02-2013

doi:10.7575/aiac.ijalel.v.2n.3p.134
Accepted: 23-03-2013

Published: 01-05-2013

\begin{abstract}
Analysis of literature indicates that varying viewpoints about different elements which define contemporary African American Literature has been identified. Majority of the scholarly works on African American writing are built on foundation of culture, political oppression and the need to express their true needs. This paper explores the current trends in contemporary African American Literature by examining tenets in poetry, fiction and drama. Through the ages African American poetry, novels and drama can be considered to a chronicle documenting the struggles of a race which has been debated, debased and their humanity violated to the fight against oppression, social and political empowerment. From the views of this paper it can be concluded that the African American writing is not simply a reflection of the chain of events that took place but was a factor in change. Most of the writers and the works which have been highlighted in this essay have shown one primary theme: the use of literature as the means to voice their anger about social and economic repression.
\end{abstract}

Keywords: social empowerment; African American literature; political promotion; fight against oppression; poetry; drama; novel

\section{Introduction}

The primary role played by African American Literature has been debated over the years (Warren, 2011; Ramperad, 1997). From the late 1970s it was observed that the effect of social movements, knowledge empowerment as well as the need to voice their concerns resulted in an increase in the number of African American scholars who emerged from different academies. This resulted in increased number of works being published and the start of African American literature being studied as a new criticism. Analysis of literature indicates that varying viewpoints about different elements which define contemporary African American Literature has been identified. Majority of the scholarly works on African American writing are built on foundation of culture, political oppression and the need to express their true needs. This paper explores the current trends in contemporary African American literature by examining tenets in poetry, fiction and drama.

\section{African American Poetry}

African American poetry is appreciated in literature to be both rageful and resolute in its beauty. Through the ages African American poetry can be considered to a chronicle documenting the struggles of a race which has been debated, debased and their humanity violated to the fight against oppression, social and political empowerment. This section of the paper identifies the various themes presented by a select few acclaimed African American poets.

Nikki Giovanni became a popular poet during the 1970s. Her work is very well appreciated for a wide range of themes including romanticism, family life, sexuality and societal issues (Fowler, 1992). Her early works including Black feeling Black talk (1968) and Black Judgment (1968) were appreciated for their revolutionary content and fight against the oppression. In her poem Ego Tripping, Giovanni writes" I am a gazelle so swift/ So swift you can't catch me". Her works sublimate the black pride. It has been indicated that Giovanni is one of the few poets of her time who has focused on other themes apart from the struggles of African Americans. In her poems in the autobiography My House (1972) she focuses on day to day struggles people face both in their family life as well as their social life. In the poems contained in this work she deals with social ideas from a broader perspective. She radiates black pride and women's pride and promotes feministic ideals (Loercher, 1973). Most of her themes centered around the growing disharmony that existed in modern day American relationships as observed in her work The Women and the Men (1975).

Claude McKay's most acclaimed book of poetry, Harlem Shadows needs to be brought to attention in this essay. The oft observed theme in this book includes the need to fight against racial injustice and the need to bring about New Negro cultural renaissance (Bloom, 1995). His frustration with respect to the inaction of the government is strongly observed in the poem, "The White House": 
"The pavement slabs burn loose beneath my feet,

And passion rends my vitals as I pass,

A chafing savage, down the decent street,

Where boldly shines your shuttered door of glass. (148)"

Apart from this work McKay is well known as the writer who published the New Negro anthem "If we must die". This poem inspired African American readers to act against the bonds of slavery and express themselves most effectively (Tillery, 1994). He was widely acclaimed as the radical "black poet at war".

While examining the works of contemporary African American poets it is important that the controversial works LeRoi Jones also called as Amiri Baraka is discussed. His early poetry is centered around the oppression African Americans face. However the controversial poetry including the Somebody Blew up America (2002) has been brought under a great deal of criticism in his poetry,

They say its some terrorist, some barbaric

Arab, in Afghanistan

It wasn't our American terrorists

It wasn't the Klan or the Skin heads

Or the them that blows up nigger

Churches, or reincarnates us on Death Row

It wasn't Trent Lott

Or David Duke or Giuliani

Or Schundler, Helms retiring

Through these lines Baraka makes an effort to identify the suffering African Americans have gone through at the hands of their own countrymen. In his poetry he condemns the call by the government to wage a war against terrorism by claiming that African Americans have always been victims of terror and that there has been few things done to bring about measures to promote their well-being.

This critical survey of contemporary African American poets would be amiss if we do not consider the work of Rita Dove. Her most critically acclaimed poetry includes the work Thomas and Beulah (1987). The poetry of Dove sublimates the idea that the folk element of the African American language is a creation of its own culture. In her collection The Other Side of the House (1988) the historical significance of the African American culture is strongly portrayed (Pereira, 2003). In her poetry Demeter Prayer to Hades, she expresses the powerful feelings a mother feels when her children leave home (Rhigaleto, 2006). Rita's strength is her ability to look beyond the oppression of African Americans and write about a wide range of other subjects as identified from the following lines

This alone is what I wish for you:

knowledge.

To understand each desire has an edge,

to know we are responsible for the lives

we change. No faith comes without cost,

no one believes without dying.

Now for the first time

I see clearly the trail you planted,

what ground opened to waste,

though you dreamed a wealth

of flowers.

\section{African American Fiction}

African American novelists have strongly been influenced by a wide range of post cultural, post-modern and postcolonial critical theories which are found to impact the overall authority and authenticity of the different themes expressed in their novels. The researcher examines the critical work of a number of contemporary African American novelists in this section of the research paper.

African American authors were found to make efforts to portray the lives of their fellow men realistically and sympathetically. The classic works made efforts to present better facets of African American life through literary expression. One of the classical works of American fiction includes works by Ralf Ellison (Ellision et al., 1995). He is 
well known to bring about racial, alienation and betrayal issues faced by African Americans today by making use of folklore, myth and complexity to drive home symbolic references to the struggles faced by African Americans. His most acclaimed work is The Invisible Man (1952). In this novel the prime focus is on the strength of humanity, the ability of human spirit and the importance of an individual to have cultural and racial identity. The main theme of the novel is identity where the nameless narrator is the invisible man, the one whose identity is unknown to others (McCaffrey, 1990). Other completed works of Ellison include his collection of short stories published in Flying Home and Other Stories (1996). In all of these works he has concentrated on prejudice faced by African Americans and attempts to drive home the view that in contemporary America there are existing problems of racial abuse and class identity. In his works he examines issues of police brutality and racial injustice from the political system. In some of his works including Afternoon, Mister Toussan portray the struggles faced by young Black men who seek recognition from their society (Warren, 2003).

There has been a great deal of attention given to fiction writing by African American women authors. Over the years these women have been silenced by neglect from publishers and when given a chance to express themselves these women expressed their role in the society, in family, in politics and in different walks of life. Since the 1970s it has been observed that African American women authors have written some powerful fiction writing. This paper examines the work of Alice Walker. The most acclaimed work of Walker was The Colour Purple (1982). This novel focused on themes related to repression of black women in America. Her story presented a theme of double repression of such women: from white community and black males.

Science fiction has been a marginalized area which has been less focused by African American writers. Some writers including Octavia Butler, Samuel Delaney and Tananrive Due were well known for their expression of class differences, race, gender and slavery. They made efforts to bring to light histories of African American communities in inspired new age fictional settings enthralling their leaders (Dickson-Carr, 2005). This paper examines the work of Samuel Delaney in this section. Samuel Delaney is one of the first acclaimed African American writers of science fiction. All of his works sublimate the underlying theme of race, gender and sexuality (Andrews et al., 2001). Delaney was criticised to have an extensive preoccupation with semiotics as well as post-modern theory even though his work was quite diverse and showed brilliant intellect and originality. His critically claimed novels range from expressions of cultural diversity, self-identity, sexual politics and femininity (Dickson-Carr, 2005). In his work Stars in My Pocket Like Grains of Sand (1984) is set out to be a romantic novel where new measures of slavery, extremes like misery as well as joy, degradation of self are all depicted driving home the view that life is transient and no matter how many experiences we go through we cannot understand the possibilities of the continuum of life (Sallis, 1996). In his series Tales of Neveryon including Neveryona (1983), Flight from Neveryong (1985) and The Bridge of Lost Desire (1987) Delaney presents a deconstruction of an ideal world and presents a political theme wherein the intersection of language and power examining cultural, religious, political and sexual entities. The main theme of this series revolves around slavery extending beyond the traditional North American experience, by showing that masters can become slaves as a result of the choices they make (McCaffrey, 1990). Most of Delay's work is largely focused on sexual, racial and gender based inequalities and struggles in today's world and challenges the reader in order to examine their social beliefs in modern day America.

\section{African American Drama}

Aristotle defines drama as the "mimesis of life on stage before a given audience" (Balogun 2010). Shakespeare in his critical evaluation draws a correlation in his description as he opines that "life is but a stage" (Ibrahim and Akande F.F, 2000). By implication, life is a drama, and all humans are characters, taking actions from God's ordained-plot structure of the universe.

From the African American point of view, drama, which is one of the three genres of literature including prose and poetry, replicates the activities of man through the use of characterization, dialogue, costumes, etc., presented on a stage in the presence of a given audience. Drama is an imitation of the real world because the characters in action only represent and imitate some preconceived personalities in the real world. This is of particular importance to African American theatre because most of it is based on real life events and are largely political in nature (Harris, 2007).

World War II brought to light the large number of struggles faced by African Americans. Examination of African American Drama is required to highlight the role of Paul Green and Richard Wright. They brought out the famous play Native Son (1941). In this play they build through a series of dramatic events the struggles of a young African American boy who is criminally inclined. The play reflects the introspection of the main character who comes to terms with his guilt as he feels that made an impact on the security "whites" felt. A number of Broadway musicals made the attempt to bring to light the problems of the black community. These include the works of a White American Harold Arlen who wrote several musicals casting African Americans and brought to light the way America refused to see the plights of one of their own in the works St Louis Woman (1946) and House of Flowers (1954).

In the 1960s it was observed that there was increase in the number of protest plays. To be brought to notice is The Slave (1965) and The Toilet (1965) by Amiri Baraka. Both these plays brought to light the growing unrest among the African American community and made efforts to identify the differences in socio demographics between the American "white" and "black" population. 


\section{Conclusion}

While some including Baraka (2011) and Neal (2011) insist that the role of African American writing is to promote the well-being of the community by contributing to works whose primary purpose is to ensure social and political empowerment. They are of the view that African American literature should promote works which is understood by the black community by portraying their real life struggles and experiences and be used as a tool for political resistance. In contrast others including Baldwin (1949), Ellision (2011) and Johnson (1997) feel that this is undue pressure on artists. They are of the view that writers should be able to experience artistic freedom and integrity, should focus on style language and aesthetics instead of a political agenda and should be able to write on a wide range of subjects. African American literary criticism therefore recognizes skilfully applied content of indigenised substance and language as tenet of modern African literature.

Many critics, such as Jarret (2006), McDowell and Spillers (1997) and Gates (1998) hail the linguistic, thematic, and aesthetic hybridism of this style as African American's literary identity and unique contribution to world literature. It is identified that in the African American context, the task that faces a creative writer is more than that of adapting to the reality of contemporary lives of the black community. It involves rather a total appreciation of the African American culture and tradition in order to bring their expression into a living relationship with the tradition of literature.

During the contemporary era African American writers moved past the focus on slavery and focused on other issues. During this period there was a conflict among the writers with respect to identifying the duty of an artist to use a political agenda to influence their work and move past the same to focus on other aspects. It can be concluded that the African American writing is not simply a reflection of the chain of events that took place but was a factor in change. Most of the writers and the works which have been highlighted in this essay have shown one primary theme: the use of literature as the means to voice their anger about social and economic repression.

\section{References}

Andrews, W, L., Foster, F. S., \& Harris, T. (2001). The Concise Oxford Companion to African American Literature. New York: Oxford, 104-105.

Baldwin, J. (1997). Everybody's protest novel. In H. L. Gates \& N. Y. McKay (Eds.), The Norton anthology of African American literature (pp. 1654-1659), New York: W.W. Norton \& Co.

Baraka, A. (2011). Enter the middle class. In H. L. Gates \& J. Burton (Eds), Call and response: key debates in African American studies (pp. 694-697). New York: Norton \& Co.

Bloom, H. (1995). Black American Poets and Dramatists of the Harlem Renaissance. New York: Chelsea House.

Dickson-Carr, D., \& Dickson-Carr, D. (2005). The Columbia Guide to Contemporary African American Fiction, New York: Columbia, 90.

Ellison, R., Graham, M., \& Singh, A. (1995). Conversations with Ralph Ellison. Jackson: University of Mississippi.

Ellison, R. (2011). The world and the jug. In H. L. Gates \& J. Burton (Eds.), Call and response: Key debates in African American studies (pp. 670-686), New York: W.W. Norton \& Co.

Fowler, V. C. (1992). Nikki Giovanni. New York: Twayne, 45-49.

Gates, H. L. (1998). What's love got to do with it?: Critical theory, integrity, and the blackIdiom. In P. L. Hill.Boston (pp. 469-1480) (Ed.), Call and response: The Riverside anthology of the African American literary tradition.

Harris, T. (2007). Reading Contemporary African American Drama: Fragments of History, Fragments of Self. New York: Peter Lang.

Jarret, G. A. (2006). Introduction: Not necessarily race matter. In Jarret, G. A. (Ed.), AfricanAmerican literature beyond race: An alternative reader (pp. 1-22). New York University Press: New York.

Johnson, J. W. (1997). Preface from The book of American Negro poetry. In H. L. Gates \& N.Y. McKay (Ed.), The Norton anthology of African American literature (pp. 861-884). New York: W.W. Norton \& Co.

Loercher, D. (1973). Nikki Giovanni's poems radiate Black Pride, Woman Pride. The Christian Science Monitor.

McCaffery, L. (1990). Across the Wounded Galaxies: Interviews with Contemporary American Science Fiction Writers. Urbana: University of Illinois.

Neal, L. (2011). The black arts movement. In H. L. Gates \& J. Burton (Eds.), Call and response: key debates in African American studies (pp. 702-711). W.W. Norton \& Co.: New York.

Pereira, M. (2003). Rita Dove's Cosmopolitanism. Urbana: University of Illinois.

Ramperad, A. (1993). Introduction to Harper Perennial edition. In R. Wright (Ed.), Native son and how "Bigger" was born. New York: Harper Perennial.

Righelato, P. (2006). Understanding Rita Dove. Columbia: University of South Carolina.

Sallis, J. (1996). Ash of Stars: On the Writing of Samuel R. Delany. Jackson: University of Mississippi.

Tillery, T. (1992). Claude McKay: A Black Poet's Struggle for Identity. Amherst: University of Massachusetts.

Warren, K. W. (2003). So Black and Blue: Ralph Ellison and the Occasion of Criticism. Chicago: University of Chicago.

Wright, R. (2011). Between laughter and tears: A review of Hurston's Their eyes are watching God. In H. L. Gates \& J. Burton (Eds.), Call and response: Key debates in African American studies (pp. 479-481). New York: W.W. Norton \& Co. 